\title{
Membangun Peradaban Masyarakat dengan Pendidikan Karakter Berbasis Kearifan Lokal di Dusun Banlanjang Tlonto Raja Pasean
}

\author{
${ }^{1}$ Moh Hafid Effendy, Usman, Hesty Kusumawati \\ Institut Agama Islam Negeri Madura \\ 1'hafideffendy@iainmadura.ac.id
}

\begin{abstract}
This article is an implementation of community service activities carried out by a team of lecturers in the Indonesian Tadris Study Program in early July 2019 located in the village of Banlanjang Tlonto Raja Pasean. In the context of counseling, the cultivation of character education for the community is for social improvement and advancement of the nation's civilization that upholds the integrity of values and humanity. The hope of character education counseling is to achieve a balance between knowledge and morals. One approach to character education is with religious education which is applied in every academic life. If knowledge and religion can be integrated, the perfection of science based on morality (excellent with morality) develops. "Knowledge without religion will be blind, religion without knowledge will be paralyzed." The results of counseling showed that the cultivation of character education in the people of Dusun Banlanjang is still not optimal, this is still constrained by family factors, that there are still many parents who leave their children because they migrate as migrant workers in Malaysia and in Saudi Arabia. So that the planting of character education based on local wisdom is still not optimal, but the values of local wisdom in the form of religious, hard work, and social care still exist applied by the community.
\end{abstract}

Keywords: Civilization, character education, local wisdom

\begin{abstract}
Abstrak
Artikel ini merupakan implementasi dari kegiatan pengabdian kepada masyarakat yang dilakukan oleh tim dosen Prodi Tadris Bahasa Indonesia yakni pada awal Juli 2019 bertempat di dusun Banlanjang Tlonto Raja Pasean. Dalam konteks penyuluhan penanaman pendidikan karakter bagi masyarakat tersebut adalah untuk perbaikan sosial dan kemajuan peradaban bangsa yang menjunjung tinggi integritas nilai dan kemanusiaan. Harapan dari penyuluhan pendidikan berkarakter adalah tercapainya keseimbangan antara pengetahuan dan moral. Salah satu pendekatan dalam pendidikan berkarakter ialah dengan pendidikan agama yang diterapkan dalam setiap kehidupan akademis. Jika pengetahuan dan agama dapat diintegrasikan maka berkembanglah kesempurnaan ilmu berlandaskan moralitas (excellent with morality). "Ilmu tanpa agama akan buta, agama tanpa ilmu akan lumpuh." Hasil penyuluhan menunjukan bahwa penanaman pendidikan karakter pada masyarakat Dusun Banlanjang masih kurang maksimal, hal ini masih terkendala faktor keluarga, bahwa masih banyak orang tua yang meninggalkan putra-putrinya karena merantau sebagai TKI di Malaysia dan di Arab Saudi. Sehingga penanaman pendidikan karakter berbasisi kearifan lokal masih belum optimal, akan tetapi nilai-nilai kearifan lokal yang berupa religius, kerja keras, dan peduli sosial masih eksis diterapkan oleh masyarakat tersebut.
\end{abstract}

Kata Kunci: Peradaban masyarakat, pendidikan karakter, kearifan lokal

\section{Pendahuluan}

Pengabdian Kepada Masyarakat (PKM) adalah suatu kegiatan dosen dalam bentuk kegiatan mengabdi kepada masyarakat yang berkaitan dengan program pendidikan Perguruan Tinggi secara totalitas dan sekaligus PKM merupakan implementasi dari Tri Darma Perguruan Tinggi yang harus dilakukan oleh para dosen di perguruan tinggi. PKM merupakan upaya sivitas akademika untuk menjembatani 
kajian-kajian teoretis di kampus dengan fenomena empiris di masyarakat, sehingga dengan adanya PKM ini dosen benar-benar bisa merasakan keadaan sebenarnya di lingkungan masyarakat serta memberikan solusi pemecahan masalah yang sedang dihadapi. Tri dharma perguruan tinggi tersebut berisikan pendidikan, penelitian dan pengabdian.

Dalam kegiatan ini, kami mengangkat tema tentang "Membangun Peradaban Masyarakat dengan Pendidikan Karakter Berbasis Kearifan Lokal di Dusun Banlanjang Tlonto Raja Pasean". Di samping itu, belakangan ini pemerintah gencar mengampanyekan Pendidikan Karakter di Indonesia. Pendidikan Karakter diyakini mampu menjadi penyembuh problem kemasyarakatan yang semakin terjerembab dalam kasus asusila, anarkisme dan tindakan korupsi di berbagai bidang kehidupan. Sebelum lebih jauh berbicara tentang pendidikan karakter, perlu diketahui bahwa karakter yang penulis maksud bukan sekedar berupa baiknya perkataan dan sikapnya saja, melainkan sebuah pilihan yang membawa kesuksesan. Dalam konteks ini, karakter bukan sebuah anugerah yang tiba-tiba ada, melainkan dibangun sedikit demi sedikit, dengan pikiran, perkataan, perbuatan, kebiasaan, keberanian usaha keras dan bahkan dibentuk dari kesulitan hidup. Kebiasaan berbuat baik tidak selalu menjamin bahwa seseorang yang telah terbiasa tersebut secara sadar (cognitive development) menghargai pentingnya nilai karakter (valuing). Karena mungkin saja perbuatannya tersebut dilandasi oleh rasa takut untuk berbuat salah, bukan karena tingginya penghargaan akan nilai kebaikan tersebut. Sebagai contoh saja ketika seseorang berbuat jujur hal itu dilakukannya karena ia takut dinilai buruk oleh orang lain, bukan karena keinginannya yang tulus untuk menghargai nilai kejujuran itu sendiri. Oleh sebab itu, dalam pelaksanaan pendidikan karakter diperlukan penguatan aspek perasaan (affective development). Komponen ini dalam pendidikan karakter disebut desiring the good atau keinginan untuk berbuat kebaikan. Ketika tanpa aspek tersebut, seseorang hanya akan sama seperti robot yang terindoktrinasi oleh sesuatu paham dan hanya mengerjakan sesuatu ketika mendapatkan komando serta perintah.

Di samping itu, pendidikan karakter mengajarkan kebiasaan cara berpikir dan perilaku yang membantu individu untuk hidup dan bekerja bersama sebagai keluarga, masyarakat dan bernegara dan membantu mereka untuk membuat keputusan yang dapat dipertanggungjawabkan. Pendidikan karakter mencoba membantu anak untuk melaksanakan perilaku yang baik, santun dan disiplin secara terus menerus, sehingga hal-hal tersebut secara relatif menjadi mudah untuk dilakukan oleh anak serta secara relatif anak menjadi merasa tidak biasa untuk melakukan hal-hal sebaliknya. Sebagaimana diketahui, setiap manusia memiliki potensi bawaan yang akan termanisfestasi setelah dia dilahirkan, termasuk potensi yang terkait dengan karakter atau nilai-nilai kebajikan. Dalam hal ini, Confusius -seorang filsuf terkenal Cina-menyatakan bahwa anak pada dasarnya memiliki potensi mencintai kebajikan, namun bila potensi ini tidak diikuti dengan pendidikan dan sosialisasi setelah anak dilahirkan, maka anak dapat berubah menjadi binatang, bahkan lebih buruk lagi.

Di sisi lain, sosialisasi dan pendidikan masyarakat yang berkaitan dengan nilai-nilai kebajikan baik di keluarga, sekolah, maupun lingkungan yang lebih luas sangat penting dalam pembentukan karakter seseorang. Dari paparan tersebut dapat disimpulkan bahwa karakter merupakan kualitas moral dan mental seseorang yang pembentukannya dipengaruhi oleh faktor bawaan (nature) dan lingkungan (nurture). Potensi karakter yang baik dimiliki anak sebelum dilahirkan, tetapi potensi tersebut harus terus-menerus dibina melalui sosialisasi dan pendidikan. Perlu diketahui bersama, bahwa desain pendidikan karakter bergerak dari knowing menuju doing atau acting. William Kilpatrick menyebutkan salah satu penyebab ketidakmampuan seseorang berlaku baik meskipun ia telah memiliki pengetahuan tentang kebaikan itu (moral knowing) adalah karena ia tidak terlatih untuk melakukan kebaikan (moral doing) Di sisi lain, moral knowing sebagai aspek pertama memiliki enam unsur, yaitu Pertama, kesadaran moral (moral awareness), yaitu kesediaan 
seseorang untuk menerima secara cerdas sesuatu yang seharusnya dilakukan. Kedua, pengetahuan tentang nilai-nilai moral (knowing moral values), yaitu mencakup pemahaman mengenai macam-macam nilai moral seperti menghormati hak hidup, kebebasan, tanggung jawab, kejujuran, keadilan, tenggang rasa, kesopanan dan kedisiplinan. Ketiga, Penentuan sudut pandang (perspective taking), yaitu kemampuan menggunakan cara pandang orang lain dalam melihat sesuatu. Keempat, Logika moral (moral reasoning), adalah kemampuan individu untuk mencari jawaban atas pertanyaan mengapa sesuatu dikatakan baik atau buruk. Kelima, Keberanian mengambil menentukan sikap (decision making), yaitu kemampuan individu untuk memilih alternatif yang paling baik dari sekian banyak pilihan. Keenam, pengenalan diri (self knowledge), yaitu kemampuan individu untuk menilai diri sendiri. Keenam unsur adalah komponen-komponen yang harus diajarkan untuk mengisi ranah kognitif mereka.

Oleh karena itu, penanaman karakter pada anak merupakan proses penyesuaian kepribadian yang perlu memperhatikan bermacam-macam prinsip dasar pertumbuhan. Salah satu nilai yang dapat dijadikan sebagai pijakan pembangunan karakter anak adalah nilai-nilai kebaikan sebuah daerah yang sudah mengakar kuat sebagai sistem budaya, yang kemudian disebut sebagai "kearifan lokal". Kearifan lokal menjadi sebuah tawaran yang menarik untuk pengembangan pendidikan karakter, karena pada dasarnya pengembangan karakter harus diikuti dengan pengintegrasian jati diri kebangsaan pada diri anak, jati diri kebangsaan atau nasionalisme pasti akan berkait erat dengan jejaring kebudayaan bangsa yang menjadi basis kebudayaan nasional. Sehingga dengan adanya pengabdian kepada masyarakat berupa penyuluhan tentang penanaman pendidikan karakter berbasis kearifan lokal diharapkan akan bisa mempertahankan dan melestarikan tradisi lokal yang santun dan bijaksana.

Berdasarkan beberapa paparan tersebut, kami mencoba melakukan pengabdian masyarakat melalui penyuluhan paparan pengetahuan tentang "Membangun Peradaban Masyarakat dengan Pendidikan Karakter Berbasis Kearifan Lokal di Dusun Banlanjang Tlonto Raja Pasean."

\section{Metode}

Hasil Pengabdian Masyarakat ini dilakukan untuk mendeskripsikan Peradaban Masyarakat dengan Pendidikan Karakter yang terdapat dalam fenomena sosial, dan budaya yang terdapat pada masyarakat di Dusun Banlanjang Tloto Raja pasean yang berada di sekitar Masjid Al-Muttaqin. Oleh karena itu, data penelitian dianalisis dengan menggunakan metode deskriptif kualitatif. Adapun teknik pengumpulan datanya melalui observasi dan dokumentasi. Sedangkan langkah-langkah analisis data dilakukan dengan cara (1) Reduksi Data, (2) Penyajian Data. (3) penarikan kesimpulan.

\section{Hasil dan Pembahasan \\ 1. Konsep pendidikan karakter}

Secara etimologis, kata karakter berasal dari bahasa yunani charassein yang berarti membuat tajam, membuat dalam. ${ }^{1}$ Secara harfiah, istilah karakter berasal dari bahasa inggris "character" yang berarti watak atau sifat. ${ }^{2}$ Dalam Kamus Bahasa Indonesia, watak diartikan sebagai sifat batin manusia yang mempengaruhi segenap pikiran dan perbuatannya, atau berarti tabiat dan budi pekerti. ${ }^{3}$ Karakter terdiri dari watak, akhlak dan budi pekerti yang diwujudkan melalui nilai-nilai moral yang dipatrikan untuk

\footnotetext{
${ }^{1}$ Lorens Bagus, Kamus Filsafat, (Jakarta: Gramedia, 1996), hlm. 396

${ }^{2}$ John M. echols dan Hasan Sadly, Kamus Inggris Indonesia, (Jakarta: Gramedia, 1979), cet. VIII, hlm. 107

${ }^{3}$ Tim Penyusun, Kamus Bahasa Indonesia, (Jakarta: Pusat Bahasa, 2008), cet.XVI, hlm. 1811
} 
menjadi nilai intrinsik dalam diri dan terwujud dalam suatu sistem daya juang. Berkarakter adalah berkepribadian, berperilaku, bersifat, bertabiat, dan watak. ${ }^{4}$ Terdapat kemiripan antara karakter dan kepribadian. Karakter merupakan kombinasi sifat-sifat dalam diri seseorang yang menjadikannya unik, berdasarkan apa yang ia sudah dimiliki sejak lahir (genetik) maupun apa yang ia pelajari dalam hidupnya.

Di samping itu, penguatan pendidikan moral (moral education) atau pendidikan karakter dalam konteks sekarang sangat relevan untuk mengatasi krisis moral yang sedang melanda di negara kita. Krisis tersebut antara lain berupa meningkatnya pergaulan bebas, maraknya angka kekerasan anak-anak dan remaja, kejahatan terhadap teman, pencurian dan perusakan milik orang lain sudah menjadi masalah sosial yang hingga saat ini belum dapat diatasi secara tuntas, oleh karena itu betapa pentingnya pendidikan karakter.

Menurut Lickona, karakter berkaitan dengan konsep moral (moral knonwing), sikap moral (moral felling), dan perilaku moral (moral behavior). Berdasarkan ketiga komponen ini dapat dinyatakanbahwa karakter yang baikdidukung oleh pengetahuan tentang kebaikan, keinginan untuk berbuat baik, dan melakukan perbuatan kebaikan. Bagan dibawah ini merupakan bagan kterkaitan ketiga kerangka pikir ini. Ada beberapa pengertian pendidikan karakter menurut ahli:

a. Pendidikan Karakter Menurut Lickona Secara sede rhana, pendidikan karakter dapat didefinisikan sebagai segala usaha yang dapat dilakukan untuk mempengaruhi karakter siswa. Tetapi untuk mengetahui pengertian yang tepat, dapat dikemukakan di sini definisi pendidikan karakter yang disampaikan oleh Thomas LickonLickona menyatakan bahwa pendidikan karakter adalah suatu usaha yang disengaja untuk membantu seseorang sehingga ia dapat memahami, memperhatikan, dan melakukan nilai-nilai etika yang inti.

b. Pendidikan Karakter Menurut Suyanto (2009) mendefinisikan kar akter sebagai cara berpikir dan berperilaku yang menjadi ciri khas tiap individu untuk hidup dan bekerja sama, baik dalam lingkup keluarga, masyarakat, bangsa, maupun negara.

c. Pendidikan Karakter Menurut Kertajaya Karakter adalah ciri khas yang dimiliki oleh suatu benda atau individu. Ciri khas tersebut adalah asli dan mengakar pada kepribadian benda atau individu tersebut, serta merupakan "mesin" yang mendorong bagaimana seorang bertindak, bersikap, berucap, dan merespon sesuatu (Kertajaya, 2010).

\section{Nilai-nilai dalam Pendidikan Karakter}

Ada 18 butir nilai-nilai pendidikan karakter yaitu, Religius, Jujur, Toleransi, Disiplin, Kerja Keras, Kreatif, Mandiri, Demokratis, Rasa Ingin Tahu, Semangat Kebangsaan, Cinta tanah air, Menghargai prestasi, Bersahabat/komunikatif, Cinta Damai, Gemar membaca, Peduli lingkungan, Peduli sosial, Tanggung jawab.Lebih jelas tentang nilai-nilai pendidikan karakter dapat di lihat pada bagan dibawah ini:

Pendidikan karakter telah menjadi perhatian berbagai negara dalam rangka mempersiapkan generasi yang berkualitas, bukan hanya untuk kepentingan individu warga negara, tetapi juga untuk warga masyarakat secara keseluruhan. Pendidikan karakter dapat diartikan sebagai the deliberate us of all dimensions of school life to foster optimal character development (usaha kita secara sengaja dari seluruh dimensi kehidupan sekolah/madrasah untuk membantu pe mbentukan karakter secara optimal. Pendidikan karakter memerlukan metode khusus yang tepat agar tujuan pendidikan dapat tercapai. Di antara metode pembelajaran yang sesuai adalah metode keteladanan, metode pembiasaan, dan metode pujian dan hukuman.

\footnotetext{
${ }^{4}$ Syaiful Sagala, Etika dan moralitas pendidikan, (Jakarta: Prenamadia Group, 2013), hlm.290-291.
} 
Dalam rangka mendukung pelaksanaan pendidikan katekter di Indonesia Kementrian Pendidikan Nasional (2011) mengidentifikasi 18 nilai yang bersumber dari agama, Pancasila, budaya, dan tujuan pendidikan nasional, yaitu: (1) religius, (2) jujur, (3) toleransi, (4) disiplin, (5) kerja keras, (6) kreatif, (7) mandiri, (8) demokratis, (9) rasa ingin tahu, (10) semangat, (11) cinta tanah air, (12) menghargai prestasi, (13) bersahabat/komunikatif, (14) cinta damai, (15) gemar membaca, (16) peduli lingkungan, (17) peduli sosial, dan (18) tanggung jawab. ${ }^{5}$

Nilai-nilai karakter yang ditetapkan oleh kementrian pendidikan ini sejalan dengan nilai- nilai kearifan lokal masyarakat Madura yang telah lebih dulu dijunjung dan dilaksnakan oleh ora ng Madura. Ole $\mathrm{h}$ ka rena itu, dalam mengimplementasikan pendidikan karakter di sekolah-sekolah yang ada di Madura nilai-nilai budaya yang ada di Madura dapat diintegrasikan dalam pembelajaran di sekolah baik formal ataupun non formal.

\section{Tinjauan tentang Kearifan Lokal}

Kearifan lokal adalah identitas atau kepribadian budaya sebuah bangsa yang menyebabkan bangsa tersebut mampu menyerap, bahkan mengolah kebudayaan yang berasal dari luar/bangsa lai menjadi watak dan kemampuan sendiri Wibowo. Identitas dan Kepribadian tersebut tentunya menyesuaikan dengan pandangan hidup masyarakat sekitar agar tidak terjadi pergesaran nilai-nilai. Kearifan lokal adalah salah satu sarana dalam mengolah kebudayaan dan mempertahankan diri dari kebudayaan asing yang tidak baik. Kearifan lokal ada lah pandangan hidup dan ilmu pengetahuan serta berbagai strategi kehidupan yang berwujud aktivitas yang dilakukan oleh masyarakat lokal dalam menjawab berbagai masalah dalam pemenuhan kebutuhan mereka. Dalam bahasa asing sering juga dikonsepsikan sebagai kebijakan setempat local wisdom atau pengetahuan setempat "local knowledge" atau kecerdasan setempat local genious.

Berbagai strategi dilakukan oleh masyarakat setempat untuk menjaga kebudayaannya. Hal senada juga diungkapkan oleh Alfian (2013:428) Kearifan lokal diartikan sebagai pandangan hidup dan pengetahuan serta sebagai strategi kehidupan yang berwujud aktifitas yang dilakukan oleh masyarakat lokal dalam meme nuhi kebutuhan mereka. Berdasarkan pendapat Alfian itu dapat diartikan 14 bahwa kearifan lokal merupakan adat dan kebiasan yang telah mentradisi dilakukan oleh sekelompok masyarakat secara turun temurun yang hingga saat ini masih dipertahankan keberadaannya oleh masyarakat hukum adat tertentu di daerah tertentu. Berdasarkan pengertian di atas dapat diartikan bahwa local wisdom (kearifan lokal) dapat dipahami sebagai gagasan-gagasan setempat lokal yang bersifat bijaksana, penuh kearifan, bernilai baik, yang tertanam dan diikuti oleh anggota masyarakatnya.

\section{Integrasi Nilai-Nilai Kepribadian ke dalam Pendidikan Berkarakter pada Masyarakat Dusun Banlanjang Tlonto Raja Kecamatan Pasean}

Keberhasilan kegiatan dikatakan sukses dan tuntas, apabila semua peserta atau partisipan dalam pengabdian memahami betul apa yang dijelaskan oleh narasumber. Oleh karena itu, merujuk pada kegiatan pengabdian tersebut, dapat dikatakan bahwa yang pertama, masyarakat sangat antusias dengan pengetahuan pendidikan karakter dalam implementasinya pada putra putri yang ada di dusun Tlonto Raja Pasean. Kedua, masyarakat telah memahami bagaimana cara mendidik anak di masa kini khususnya dalam ranah akhlak guna membangun karakter baik pada anak didik kita. guna menemukan target tercapai $100 \%$ dari tujuan yang diharapkan. Oleh karena itu, harapan tahun-tahun selanjutnya atau yang akan datang supaya dilakukan

\footnotetext{
${ }^{5}$ Muchlas Samani dan Hariyanto, Konsep dan Model Pendidikan Karakter, Bandung: Remaja Rosda Karya, 2011), hlm. 46
} 
pengabdian pengembangan dengan bidang yang sama untuk melihat potret ketuntasan dari materi yang diberikan sesuai dengan harapan. Maka berdasarkan implementasi paparan materi kepada masyarakat menunjukkan bahwa di satu sisi ada kegagalan pemahaman dalam mendidik putra-putrinya yang khususnya bapak dan ibunya bekerja di luar negeri yakni yang mayoritas orang tuanya merantau dengan bekerja di Negara Arab Saudi dan Malaysia.

Adapun bentuk kebehasilan dalam membangun pendidikan karakter yang berbasis kearifan lokal, bahwa masyarakat di Dusun Banlanjang Tlonto Raja Pasean masih kuat pada nilai-nilai religius, kerja keras, mandiri, peduli sosial, dan peduli lingkungan sekitar. Nilai kearifan lokal masih kuat diterapkan oleh masyarakat, akan tetapi cara penanamannya kepada putra-putrinya masih belum optimal.

Selain itu, karakter terkadang dipandang sebagai kepribadian atau lebih bersifat perilaku.Banyak ilmuwan psikologi yang mengabaikan fungsi kognitif pada definisi mereka mengenai karakter, namun ada juga yang lebih bersifat komprehensif.Bahkan ada ilmuwan yang menyatakan bahwa karakter merupakan suatu konstruksi social, karakter seseorang dipengaruhi oleh lingkungan sosialnya.Karakter juga dikatakan sebagai sekumpulan karakteristik psikologis individu yang mempengaruhi kemampuan seseorang dan membantu dirinya untuk dapat berfungsi secara moral. Dikarenakan sifat karakter yang plural, maka beberapa ahli pun membagi karakter itu ke dalam beberapa kategori.Kekuatan karakter dibagi menjadi 6 kelompok besar yang kemudian menurunkan 24 karakter, yaitu kognitif (wisdom and knowledge), emosional (courage/kesatriaan), interpersonal (humanity), hidup bersama (justice), menghadapi dan mengatasi hal yang tak menyenangkan (temperance), dan spiritual (transcendence). ${ }^{6}$

\section{Implementasi Pendidikan karakter di Lingkungan Keluarga di Desa Tlonto Raja Pasean}

Implementasi Pendidikan karakter di lingkungan keluarga sebagai berikut:

\section{a. Urgensi Pendidikan Karakter di lingkungan Keluarga}

Keluarga adalah pihak pertama yang paling penting dalam memengarui karakter anak dan tugas sekolah adalah memeperkuat nilai karakter positif (etos kerja, rasa hormat, tanggung jawab, jujur, dII) yang diajarkan di rumah. Keluarga meletakkan fondasi sebagai dasar, dan sekolah membangun atas fondasi itu. ${ }^{7}$ Keluarga dipandang sebagai tulang punggung pendidikan karakter. Para ahli pendidikan di Indonesia umumnya bersepakat bahwa pendidikan karakter sebaiknya dimulai sejak usia anak-anak (golden age), karena usia ini terbukti sangat menentukan kemapuan anak dalam mengambangkan potensinya. Perlu pembiasaan sejak dini dalam penanaman nilai-nilai akhlak yang baik. Keluarga yang harmonis, rukun, dan damai akan mempengaruhi kondisi psikologis dan karakter seorang anak. Begitupun sebaliknya, anak yang kurang berbakti bahkan melakukan tindakan di luar moral kemanusiaan, dibidani oleh ketidakharmonisan dalam lingkungan keluarga. ${ }^{8}$ Kebanyakan anak yang hidup dalam keluarga broken home atau berpisah, anak tersebut memiliki sifat yang apatis terhadap nilainilai norma, walaupun tidak semua anak yang mengalami broken home demikian. Hal ini terjadi karena anak tersebut kurang kasih sayang dari orang tuanya.

\section{b. Aspek Penting Pendidikan Karakter di Lingkungan Keluarga}

1) Pola interaksi antar anggota keluarga Baik buruknya hubungan atau interaksi antara suami dan istri atau ayah dan ibu sangat menentukan kesuksesan pendidikan karakter di lingkungan keluarga untuk menciptakan suasana edukatif dan interaksi

\footnotetext{
${ }^{6}$ Peterson, Christopher \& Seligman, Martin E. P. (2004).Character Strengths and Virtues: A Handbook and Classification. New York: Oxford University Press.

${ }^{7}$ Thomas Lickona, Character Matters (Persoalan Karakter), (Jakarta: Bumi Aksara, 2012), hlm. 81

8 Agus Wibowo, Pendidikan Karakter:Strategi Membangun Karakter Bangsa Berperadaban, (Yogyakarta:Pustaka Belajar, 2012), hlm.107-108
} 
edukatif. Situasi edukatif adalah terciptanya suasana yang memungkinkan terjadinya proses pendidikan. Sementara interaksi edukatif adalah interaksi yang mengandung nilai pendidikan. Situasi dan interaksi edukatif harus diciptakan oleh suami istri atau ayah ibu, dan orang-orang dewasa lain yang bertanggungjawab dalam pelaksanaan pendidikan karakter di lingkungan keluarga.

2) Interaksi antara orangtua dan anak Hal yang perlu diperhatikan orangtua dalam membangun hubungan atau interaksi yang baik dengan anaknya yakni: memposisikan dirinya sebagai sahabat bagi anak, menyediakan waktu untuk anak, dan mampu untuk mengenali bahasa tubuh dari sang anak. ${ }^{9}$

Adapun pola interaksi pada masyarakat di desa Tlonto Raja Pasean masih tergolong belum maksimal, karena mayoritas anak dan orang tua berpisah. Orang tuanya mayoritas menjadi TKI di luar negeri sedangkan anaknya diasuh saudaranya dan bahkan sepupunya. Sehingga orangtua untuk memotret perkembangan anak sangat jauh dari jangkauan, pola mendidiknya hanya melalui telepon dan pesan singkat melalui alat komunikasi. Padahal bahasa tubuh dan kontak langsung antara orang tua dan anak sangat dibutuhkan guna terjadinya sugesti yang bersahaja dan bersahabat antar keluarga.

\section{Temuan di Lapangan}

Adapun temuan dalam kegiatan pengabdian kepada masyarakat di Dusun Banlanjang Tlonto Raja Kecamatan Pasean sebagai berikut:

1. Mayoritas masyarakat di dusun Banlanjang tamat sekolah dasar dan menikah sejak dini.

2. Masyarakat di dusun Banlanjang Tlonto Raja Kecamatan Pasean bermata pencaharian sebagai petani, nelayan, dan pedagang.

3. Mayoritas masyarakat di dusun Banlanjang memiliki jiwa keras keras sampai bekerja sebagai TKI ke Malaysia dan Arab Saudi.

4. Masyarakat di dusun Banlanjang masih tetap kuat dalam menanamkan nilai-nilai religius dan memiliki kepekaan sosial dalam bermasyarakat.

\section{Kesimpulan}

Berdasarkan hasil identifikasi, dan reduksi data di lapangan tentang penanaman pendidikan karakter bagi masyarakat Dusun Banlanjang Kecamatan Pasean. Penulis dapat menyimpulkan hasil kegiatan pengabdian masyarakat sebagai berikut.

Pendidikan berkarakter adalah kunci untuk perbaikan sosial dan kemajuan peradaban bangsa yang menjunjung tinggi integritas nilai dan kemanusiaan.Harapan dari pendidikan berkarakter adalah tercapainya keseimbangan antara pengetahuan dan moral. Salah satu pendekatan dalam pendidikan berkarakter ialah dengan pendidikan agama yang diterapkan dalam setiap kehidupan akademis. Jika pengetahuan dan agama dapat diintegrasikan maka berkembanglah kesempurnaan ilmu berlandaskan moralitas (excellent with morality). "Ilmu tanpa agama akan buta, agama tanpa ilmu akan lumpuh."

Penanaman pendidikan karakter pada masyarakat Dusun Banlanjang masih kurang maksimal, hal ini masih terkendala faktor keluarga, bahwa masih banyak orang tua yang meninggalkan putra-putrinya karena merantau sebagai TKI di Malaysia dan di Arab Saudi. Sehingga penanaman pendidikan karakter berbasisi kearifan lokal masih belum optimal, akan tetapi nilai-nilai kearifan lokal yang berupa religius, kerja keras, dan peduli sosial masih eksis diterapkan oleh masyarakat.

\footnotetext{
${ }^{9}$ Moh. Haitami Salim, Pendidikan Agama Islam dalam Keluarga: Revitalisasi Peran Keluarga dalam menyiapkan Generasi bangsa yang berkarakter, (Yogyakarta: Ar-Ruzz Media, 2013), hlm 125-126.
} 


\section{Ucapan Terima Kasih}

Terimakasih kami sampaikan kepada ketua Lembaga Pengabdian Kepada Masyarakat (LP2M) IAIN Madura beserta jajarannya, karena telah bersedia meluangkan media jurnal Pengabdian Kepada Masyarakat "Pèrdikan", sehingga kami bisa ikut berpartisipasi di dalamnya. Terima kasih juga kami sampaikan kepada rekanrekan, dan pihak lain atas partisipasinya sehingga tulisan ini dapat terselesaikan.

\section{Daftar Rujukan}

Alwasilah, Chaedar. (2009). Etnopedagogi: Landasan Praktek Pendidikan dan Pendidikan Guru. Bandung: PT Kiblat Buku Utama.

Achmadi, (1992), Islam sebagai Paradigma IImu Pendidikan, Yogyakarta: Aditya Media

Afandi, Rifki, (2011), Integrasi Pendidikan Karakter dalam Pembelajaran IPS di Sekolah Dasar, Jurnal Penelitian Pendidikan

Asmani, Jamal Makmur, (2013), Buku Panduan Internalisasi Karakter di Sekolah, Yogyakarta: Diva Press.

Agus Wibowo, (2012). Pendidikan Karakter:Strategi Membangun Karakter Bangsa Berperadaban. Yogyakarta:Pustaka Belajar.

Cassirer, Ernst. (1987). Manusia dan Kebudayaan. Jakarta: Gramedia. Dharmayuda, I Made Suasthawa. 1995. Kebudayaan Bali. Denpasar: Kayumas Agung.

David Elkind \& Freddy Sweet. (2004). Caracter Education. New York : Oxford

DIRJEN DIKTI. 2010. Kerangka Acuan Pendidikan Karakter. Jakarta

Fathurroman, Pupuh, dkk, (2013), Pengembangan Pendidikan Karakter, Bandung: Refika Aditama.

Haitami Moh Salim,(2013). Pendidikan Agama Islam dalam Keluarga: Revitalisasi Peran Keluarga dalam menyiapkan Generasi bangsa yang berkarakter. Yogyakarta: Ar-Ruzz Media

Kemendiknas. (2010). "Pembinaan Pendidikan Karakter di Sekolah Menengah Pertama”. Jakarta:Badan Penelitian dan Pengembangan. . (2010). "Pengembangan Pendidikan Budaya dan Karakter bangsa". Jakarta: Badan Penelitian dan Pengembangan.

Peterson, Christopher \& Seligman, Martin E. P. (2004).Character Strengths and Virtues: A Handbook and Classification. New York: Oxford University Press.

Kementerian Pendidikan dan Kebudayaan, (2010), Pengembangan Pendidikan Budaya dan Karakter Bangsa, Jakarta: Badan Penelitian dan Pengembangan Pusat Kurikulum.

Licona, Thomas. (2013). Pendidikan Karakter: Panduan Lengkap Mendidik Siswa Menjadi Pintar dan Baik. Bandung: Nusa Media. . (2012). Character Matters (Persoalan Karakter). Jakarta: Bumi Aksara.

Muchlas Samani dan Hariyanto, (2013), Konsep dan Model Pendidikan Karakter, Keberagamaan dalam Membina Kepribadian Sehat, Jurnal Penelitian Pendidikan.

,(2011). Konsep dan Model Pendidikan Karakter, Bandung: Remaja Rosda Karya 